\title{
The Utilization of Bunker Eggs into Duck Feed in Tanjung Rejo Village, Deli Serdang Regency
}

\author{
Masitta Tanjung $^{1 *}$, Mayang Sari Yeanny ${ }^{1}$ \\ ${ }^{1}$ Faculty of Mathematics and Natural Sciences, North Sumatra University, Medan, Indonesia, \\ *Email: mayang@usu.ac.id
}

\begin{abstract}
The community service activities with the title "The Utilization of Bunker Eggs into Duck Feed in Tanjung Rejo Village, Deli Serdang Regency" will be held in May - November 2019. This activity aim is to convert bunker eggs (eggs that failed to hatch) into duck feed which has economic value and is environmentally friendly. The method used is counselling, lectures and training as well as monitoring and evaluation with the community directly to the field.The stages of duck feed production include; (1) choosing a bunker egg (2) egg waste is put into cormorant and boiled for approximately 1 hour, (3) cut water hyacinth/kale, (4) rice bran and water hyacinth/kale steamed into cormorant II which has been filled with water for approximately more than 1 hour, (5) bunker eggs, rice bran, and water hyacinth/kale are removed and drained in large containers and sacks, (6) bunker eggs are mashed without peeling the skin, (7) mixed all ingredients (endhog bunker, bran, kale) by adding enough water and stir until evenly distributed, (8) milling the mixture of materials using a special grinding to form feed, and (9) finishing includes the drying process using an oven/stove. Egg bunkers can be converted into animal feed
\end{abstract}

Keyword: : Bunker Egg, Duck Feed, Tanjung Rejo Village

\begin{abstract}
Abstrak
Kegiatan pengabdian masyarakat dengan judul "Pemanfaatan Telur Bunker menjadi Pakan Itik di Desa Tanjung Rejo, Kabupaten Deli Serdang" akan dilaksanakan pada bulan Mei - November 2019. Kegiatan ini bertujuan untuk mengkonversi telur bunker (telur yang gagal menetas) menjadi Pakan itik yang bernilai ekonomis dan ramah lingkungan. Metode yang digunakan adalah konseling, ceramah dan pelatihan serta pemantauan dan evaluasi dengan masyarakat langsung ke lapangan. Tahapan produksi pakan itik meliputi; (1) memilih telur bunker (2) limbah telur dimasukkan ke dalam kormoran dan direbus selama kurang lebih 1 jam, (3) potong eceng gondok / kangkung, (4) dedak padi dan kangkung / kale air dikukus menjadi kormoran II yang telah diisi dengan air selama kurang lebih 1 jam, (5) telur bunker, dedak padi, dan eceng gondok / kale dibuang dan dikeringkan dalam wadah dan karung besar, (6) telur bunker dihaluskan tanpa dikupas kulitnya, (7) campur semua bahan (bunker endhog, dedak, kangkung) dengan menambahkan air yang cukup dan aduk sampai merata, (8) penggilingan campuran bahan menggunakan penggilingan khusus untuk membentuk pakan, dan (9) finishing meliputi proses pengeringan menggunakan oven / kompor. Bunker telur dapat dikonversi menjadi pakan ternak
\end{abstract}

\section{Kata Kunci: Telur Bunker, Pakan Bebek, Desa Tanjung Rejo}

\section{INTRODUCTION}

Data from the Directorate General of Animal Husbandry and Animal Health / Direktorat Jenderal Peternakan dan Kesehatan Hewan (2017) indicated the total population of ducks in Sumatra Utara in 2017 reached 2.813.516 heads. Duck meat production is 43.2 tons, manila duck is 5.6 tons, duck egg production is 308.6 tons, manila duck is 35 tons..Ahmad et.al (2003) explained that eggs are composed of four basic components namely egg yolk, egg white, eggshell membrane and eggshell. Rahadianto, et.al (2013) explained that the eggshell thickness is also influenced by the type of poultry, strains and environmental temperature. According to Yuniastuti (2002) that in general the fat content in ducks is strongly influenced by the nutrition of the ration consumed. Juliambarwati 
et.al (2012) added that the protein and fat content in the feed will affect the weight of the egg. Egg weight will continue to increase along with the egg production period and achieve maximum egg weight after producing for 40 weeks. Egg weight is very important to support the selling value of eggs on the market and large eggs are much in demand by consumers, hence it also affects the income of duck farmers (Malik and Gunawan, 2008).

Laying ducks become one of the opportunities that are quite potential to be developed in the business of duck farming, because every year the demand for duck eggs tends to increase, in addition to being a source of family protein, duck eggs are widely used as ingredients for making various cakes and so forth.Therefore laying ducks become one of the promising and profitable business alternatives that can be relied upon as a source of family income. However, not all eggs produced can be utilized because there are less good eggs like egg bunkers, which is eggs that failed to hatch.

In the village of Tanjung Rejo, groups of Breeder, especially duck breeders, have always had difficulty using bunker eggs, which are eggs that have failed to hatch, most Breeders simply throw them away. Only a small portion uses it as feed and this feed must be used up as soon as possible so as not to cause odour.Apart from that, the egg bunker is annoying if just throw it away and leaves it like trash. The used of egg bunkers as economic animal feed, high nutritional value and environmentally friendly.

Economically, bunker as animal feed is very useful because the composition is mixed in feed and can be stored for a long time. Usually, breeders mix their rations for ducks, such as rice bran, corn, concentrates, vitamins, and others. This was complained by the duck breeders because they had to buy per item of the mixed duck ration.

A feed is a mixture of various kinds of organic and inorganic matters provided to livestock and poultry to meet the needs of food substances needed for growth, development and production. For maximum growth and production, the amount and content of nutrients needed by livestock/poultry must be adequate (Suprijatna et al., 2010). The nutritional value is high because based on the results of proximate tests at the UGM Food and Agricultural Product Laboratory, the bunker feed product with the following detailed results.

\begin{tabular}{lllc}
\hline Sample & Parameter & \multicolumn{2}{l}{ Analysis Results (\%) } \\
& & UL 1 & UL 2 \\
\hline Duck Feed & Water & 15,0723 & 15,1661 \\
Bunker & Ash & 13,0938 & 13,3050 \\
& Protein $(\mathrm{fk}=6,25)$ & 12,6842 & 12,4758 \\
& Fat & 15,7375 & 15,3116 \\
& Coarse Fiber & 15,3604 & 15,9419 \\
\hline
\end{tabular}

Table 1. Proximate Test Analysis Results of Bunker Feed Products

The bunker feed is also environmentally friendly because the waste of eggs that fail to hatch can be utilized maximally and not become garbage. As well as water hyacinth/water spinach as a mixture are found a lot in the village, whose growth is very disturbing the waters can be used while preserving the environment.Kale waste contains crude fibre. Denbow (2000) explained that the amount of digestible crude fibre in poultry ranges from $5-10 \%$ of the amount of crude fibre. The results of Intannita's research (2003) explained that the use of a $10 \%$ level of water spinach $/ \mathrm{kale}$ waste on Mandalung Duck has the best influence on the growth of ducks.

Based on this condition and situation, the community service team conducted the services in the village of Tanjung Rejo, Percut Sei Tuan Subdistrict, Deli Serdang Regency with the village community, especially the duck breeder group.

\section{METHODS}


The method offered in this activity will be carried out by a combination of counselling, training, hands-on practice and work evaluation. This activity was supported by the village chief and the officials will play a role in helping this implementation by giving permission and contacting breeders' community groups. While the benefits obtained will increase the knowledge of human resources in terms of utilization of bunker egg waste as animal feed.

The Breeder Group acts as the object of utilizing bunker egg waste as animal feed. The benefits obtained by breeders will increase knowledge, save the environment from waste and will ultimately help the economy and will improve their living standards.

In this service, the breeder group can cooperate in making animal feed, because breeders need these products. In making feed is very easy, practical, economical, and inexpensive, only requires a little time and anyone can do it.Likewise the ingredients, are available in the community and it is one alternative that is very appropriate to overcome the scarcity and rising of animal feed cost. Working methods of this animal feed can be seen as follows:

\subsection{Method of collecting data}

The collection method is done by:

1. Interview: By taking primary data through interviewing the local community.

2. Field Observation: Field observations were carried out with the community.

3. Literature study: Literature study was carried out to complement the information obtained regarding the manufacture and application of bunker egg waste animal feed to be made optimally.

\subsection{Approach Method}

This method was done by conducting counselling, training, direct practice to the surrounding community on how to make and implement methods of making duck feed.It is intended that the surrounding community can reduce the expenditure of excess funds to provide animal feed. As this animal feed is healthier and has high nutritional value and also environmentally friendly

\subsection{Method of Implementation}

\subsubsection{Tools used}

To make a Bunker feed product, equipment such as (1) a gas stove is used as a tool to assist in the production of Bunker, (2) gas cylinders, used as a tool that helps in finalizing Bunker production, (3) winnowing tray used as a drying device after the Bunker production preparation stage,(4) pot/cormorant used to steam rice bran mixed with water spinach or water hyacinth, (5) masks, used to maintain the health of producers and ducks when production takes place, as well as to avoid the pungent odor of egg bunkers, (6) gloves used to maintain the health of producers and ducks, hence the production of Bunker is more hygienic, (7) a knife, used to cut water spinach or water hyacinth, (8) cutting boards, used as a base to help cut water spinach or water hyacinth, (9) meat grinder, used to print Bunker products, (10) oven, used to dry the product in an effort to minimize mold, (11) the scale, used to measure the weight of the Bunker product to be marketed,and (12) plastic packaging, used to place Bunker products that are ready to be marketed.

\subsubsection{Preparation phase}

The preparation phase includes the preparation of all the materials needed, which are egg bunkers, rice bran, water hyacinth/water spinach, water, and other supporting equipment.

\subsubsection{Production Stage}

The production phase includes (1) selecting bunker eggs with the characteristics of no black spots when candling or binoculars, eggs that have bloodstains, cracked eggshells, eggs which on the 20th day have not hatched, sweat, and embryos have appeared on the inside, (2) egg waste is put into cormorant I which has been filled with water and boiled for approximately 1 hour, (3) cutting water hyacinth/kale, (4) rice bran and water hyacinth/kale steamed into cormorant II which has 
been filled with water for approximately 1 hour, (5) Bunker eggs, rice bran, and boiled water hyacinth/kale were removed and drained in large containers and sacks,(6) bunker eggs are mashed without peeling the skin, (7) mix all ingredients (endhog bunkers, bran, kale/water spinach) by adding enough water and stir until evenly distributed, (8) grind the mixture of materials using a special grinding to form feed, and (9) finishing includes the drying process using an oven/stove.

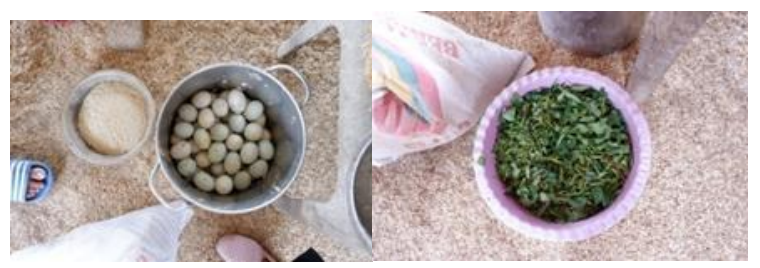

Figure 1. Bunker eggs and rice bran (left) and hyacinth/kale (right)

\section{RESULT AND DISCUSSION}

This activity was carried out by a combination of counseling, training, hands-on practice and work evaluation. This activity was supported by the village chief and the officials will play a role in helping this implementation by giving permission, contacting the Tanjung Rejo village community group.While the benefits gained will increase the knowledge of human resources in terms of the bunker eggs utilization into duck feed for the benefit of the Tanjung Rejo village community

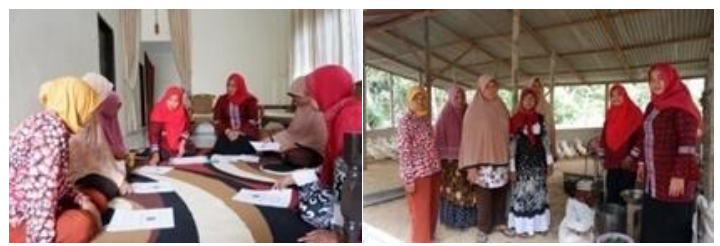

Figure 2 . Theory presented by team (left) and practiced by team and community (right).

The Tanjung Rejo village breeders group acts as the object of the bunker eggs utilization. The benefits gained will increase public knowledge about the use of bunker eggs into duck feed for the benefit of the duck breeders community.Besides that, this is also a very appropriate alternative to overcome the scarcity and rising prices of animal feed and the environment becomes more sustainable. Hence the villagers can save the environment and improve the standard living of their families.

The bunker feed product has the potential to continue because it is easy to obtain the raw materials in the form of bunker eggs and water hyacinth, it has been tested quality in the UGM Food and Agriculture Laboratory, it is more economical compared to the duck breeders make their ration, and environmentally friendly because it utilizes waste Duck bunker eggs (Elsola et.al., 2015).

The use of water spinach/kale in duck feed has a positive effect on the thickness of the eggshell because it can increase the thickness of the eggshell. Eggshells are the outermost part of the eggs and it is important to note their quality, because eggshells protect the contents of the egg from the entry of bacteria that cause damage to the contents of the egg which can result in decreased egg quality (Amo, et.al, 2013).

By utilizing bunker eggs into duck feed, it is hoped that the Tanjung Rejo Village breeders group can reduce production costs because they can obtain and produce their duck feed from bunker eggs according to their needs. 


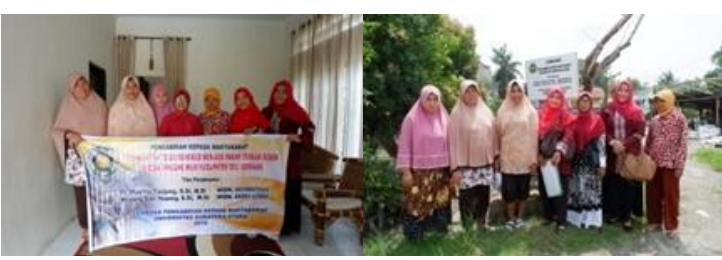

Figure 3. The team who conducted the social engangement from USU and communities at Tanjung Rejo.

\section{CONCLUSION}

Based on the community service activities regarding the utilization of bunker eggs to feed duck in

Deli Serdang Regency, the following conclusions can be drawn:

1. Utilization of egg bunkers can be converted into animal feed.

2. Utilization of egg bunkers can provide economic and ecological value.

3. There is good collaboration between USU and the community in Tanjung Rejo village, Deli Serdang Regency.

\section{ACKNOWLEDGMENTS}

We would like to thank to the Rector of USU for finantial support by Mono Tahun Social Engagement Non PNBP 2019 and all participants who have helped the implementation of this Community.

\section{REFERENCES}

Ahmad, H. A., S. S. Yadalam. and D. A. Roland. 2003. Calcium requirement of bovanes hens. Poultry Science Department, Auburn University. USA. International Journal of Poultry Science. 2 (6): 417-420.

Amo, M., J. L. P. Saerang, M. Najoan dan J. Keintjem. 2013. Pengaruh Penambahan Tepung Kunyit (Curcuma domestica val) dalam Ransum terhadap Kualitas Telur Puyuh (Cortunixcortunix japonica). Fakultas Peternakan Univrsitas Sam Ratulangi. Manado. Jurnal Zootek Vol. 33, No. 1: 48-57 ISSN 0852-2626.

Denbow, D. M. 2000. Gastrointestinal anatomy and physiology. dalam: Sturkie's Avian Physiology. Whittow, G. C. (Editor). Academic Press, London. Pages: 299-325.

Direktorat Jenderal Peternakan dan Kesehatan Hewan (2017). Staistik Peternakan dan Kesehatan Hewan. ISBN : 978-979-628-034-6

Elsola, D. A. N, N. P. Arum, A.P. Utami dan P. S. Nurkhaffah. Donker: Pakan Bebek yang Ekonomis dan Ramah Lingkungan dari Limbah Telur Bebek.Universitas Negeri Yogyakarta, PELITA, Volume X, Nomor 2, Agustus 2015

Intannita, T. 2003. Performans Mandalung (Mule Duck) dengan Taraf Penambahan Kangkung (Ipomoea aquatica) yang Berbeda dalam Ransum. Skripsi.Fakultas Peternakan Institut Pertanian Bogor. Bogor.

Juliambarwati, M., A. Ratriyanto dan A. Hanifa. 2012. Pengaruh Penggunaan Tepung Limbah Udang dalam Ransum Terhadap Kualitas Telur Bebek. Prodi Peternakan Fakultas Peternakan Universitas Sebelas Maret. Sains Peternakan Vol. 10 (1), 1-6 ISSN 1693-8828. 
Malik, A. dan A. Gunawan. 2008. Efek Penyuntikan Dosis Rendah Hormon Gonadotropin Terhadap Besar Telur Itik Mojosari. Fakultas Pertanian Universitas Islam Kalimantan (Uniska). Banjarmasin. Jurnal Ilmu Ternak Vol. 8, No. 1, Pages: 91-94.

Suprijatna, E. 2010. Strategi Pengembangan Ayam Lokal berbasis Sumber Daya Lokal dan Berwawasan Lingkungan. Prosiding Seminar Nasional Unggas Lokal ke IV. Pages: 55 - 79.

Rahadianto, A., O . Sjofjan., dan I. H. Djumadi. 2013. Efek Penambahan Beberapa Sumber Kalsium dalam Pakan terhadap Kualitas Eksternal Telur Ayam Petelur. Fakultas Peternakan, Universitas Brawijaya, Malang

Yuniastuti, A. 2002. Efek pakan berserat pada ransum ayam terhadap kadar lemak dan kolesterol daging ayam broiler. Jurnal Ilmiah Sainteks IX (3): 175-183. 